\title{
An evaluation of the method used in digestibility estimations of a dietary ingredient and comparisons on external and internal markers, and time of faeces collection in digestibility studies in the fish Oreochromis aureus (Steindachner)
}

\author{
SS De Silva*, KF Shim, A Khim Ong \\ National University of Singapore, Department of Zoology, Kent Ridge Crescent, \\ Singapore 0511
}

(Received 22 August 1989; accepted 9 January 1990)

\begin{abstract}
Summary - Results of experiments carried out on the tilapiine fish Oreochromis aureus (Steindachner) to evaluate the method used in the determination of the apparent dry matter and nutrient digestibilities of an ingredient, together with validity of estimations based on day and night collection of faeces, and internal and external markers, are presented. The apparent dry matter and protein digestibilities of the test diets were linearly correlated to the percent substitution of the test ingredient, percent fibre and ash in the test diets $(P<0.05)$; the correlation coefficient for the individual relationships decreased in that order. Dry matter or protein digestibilities were not correlated to the dietary protein content $(P>0.05)$. Similarly there were no statistical differences between digestibility estimations based on faecal material, voided in the day or the night; and estimated using different markers viz crude fibre and $\mathrm{Cr}_{2} \mathrm{O}_{3}$. The apparent dry matter and protein digestibilities of the test ingredients, leaf meal, were curvilinearly related to the percent substitution of the ingredient in the test diets. The ingredient digestibilities estimated, using crude fibre as the marker, were consistently higher than those estimated with $\mathrm{Cr}_{2} \mathrm{O}_{3}(P<0.05)$. The present study suggests that, for ingredient digestibility estimations, test diets prepared by mixing $15-20 \%$ of the ingredient to a reference diet would be more desirable.
\end{abstract}

digestibility / ingredient / cichlid / marker / diet

Résumé - Evaluation de la méthode utilisée pour estimer la digestibilité d'un ingrédient allmentaire et comparaison de marqueurs externes et internes et du temps de collecte des faeces dans les études de digestibilité chez le poisson Oreochromis aureus (Steindachner). Le but des expériences présentées était d'évaluer, chez le Poisson Oreochromis aureus (Steindachner), la méthode utilisée pour déterminer la digestibilité de la matière sèche et des nutriments d'un aliment, ainsi que la validité des estimations basées sur la collecte diurne et nocturne des faeces et l'emploi de marqueurs internes et externes. La digestibilité apparente de la matière sèche et des protéines des régimes témoins était corrélée de façon linéaire au pourcentage de substitution de l'ingrédient testé, au pourcentage des fibres et au pourcentage des cendres dans le régime ( $\mathrm{P}<0,05$ ), le coefficient de corrélation pour les relations individuelles diminuant dans cet ordre. Les digestibilités de la matière sèche et des protéines n'étaient pas orrélées au taux de protéines du régime $(\mathrm{P}>0,05)$. De même, il n'y avait pas de différence significative entre les estimations de la digestibili-

\footnotetext{
* Correspondence and reprints
} 
té basées sur les collectes diurnes ou nocturnes des faeces, ou estimées en utilisant différents marqueurs (fibre brute ou $\mathrm{Cr}_{2} \mathrm{O}_{3}$ ). Une relation curvilinéaire a été mise en évidence entre la digestibilité apparente de la matière sèche et des protéines de la farine de feville et son pourcentage de nutrition dans le régime. Les digestibilités de l'ingrédient estimées à l'aide de la fibre brute comme marqueur étaient nettement supérieures à celles obtenues à l'aide de $\mathrm{Cr}_{2} \mathrm{O}_{3}(\mathrm{P}<0,05)$. Les résultats obtenus suggèrent qu'il est souhaitable d'introduire dans le régime témoin 15 à $20 \%$ de l'ingrédient à étudier pour mesurer la digestibilité.

digestibilité / ingrédient / Cichlidé / marqueur / régime alimentaire

\section{INTRODUCTION}

There is an increasing emphasis on the development of low-cost diets using agricultural by-products in fish culture. Effective incorporation of an ingredient into fish diets involves the basic step of evaluating its digestibility. The digestibility of individual ingredients are evaluated using the method suggested by Cho et al (1982), where $30 \%$ of the ingredient to be tested is mixed into a reference diet, the digestibilities of the reference and the test diets are estimated independently and the ingredient digestibility calculated (Cho et al, 1985). There has only been one study to evaluate whether the test diet composition of $30 \%$ ingredient and $70 \%$ reference diet is the most suitable (Spyridakis et al, 1988).

Apart from these two other aspects, amongst others, what remains controversial with respect to digestibility estimations in fish, are the use of internal and external markers (Bowen, 1978; De Silva and Perera, 1983; Tacon and Rodrigues, 1984) and the time of collection of faeces and consequent pooling of faecal samples for analyses (De Silva and Perera, 1984; Spyridakis et al, 1989).

In this paper, results of digestibility experiments on the cichlid fish Oreochromis aureus (Steindachner), designed to address these questions, are presented.
Specifically, what is the most suitable amount of test ingredient to be mixed with the reference diet in estimating the total and protein digestibility of the former, whether the digestibility estimations made, using an internal or an external marker, are more reliable/realistic and whether faeces voided, during the day-time or the night, are more suitable for digestibility estimations.

\section{MATERIALS AND METHODS}

Experiments were carried out in glass tanks of $60 \times 35 \times 30 \mathrm{~cm}$, stocked with 25 fish of mean weight $14.8 \mathrm{~g}$ (range $6.6-22.6 \mathrm{~g}$; $\mathrm{SD} \pm 4.41$ ). The tanks were provided with $12 \mathrm{~h}$ light/ $12 \mathrm{~h}$ dark photoregime and constant aeration. The experimental temperature was $25.7 \pm 0.8^{\circ} \mathrm{C}$.

Fish were acclimatised to 1 of the 7 diets, assigned randomly, for a period of $14 \mathrm{~d}$ prior to faecal collection for analysis. The assigned diets were fed at $0900 \mathrm{~h}$, and between 1600-1630 h, to satiation. Prior to feeding, faecal material collected was siphoned out, and similarly, any left over food was siphoned after each feeding.

The tanks were kept at a slight angle, which enhanced the accumulation of faecal material at 1 end. A fine wire mesh was placed at the bottom of the tanks to prevent the ingestion of any faecal material between feedings. Care was taken to prevent the breaking up of faecal strands when siphoning. Excess water was drained from the siphoned faecal material, dried at $80^{\circ} \mathrm{C}$ overnight and kept in air tight vials until ready for chemical analyses. Faecal collections made in the morning (prior to the first feeding; voided between 1630-0900 h), and in the afternoon (prior 
to the 2nd feeding; voided between 0930$1630 \mathrm{~h}$ ), were kept separately for each group of fish.

As the amount of faeces in any 1 collection was insufficient to complete all chemical analyses, for each group of fish, faeces voided during day and night were pooled for 7 and 4 consecutive $\mathrm{d}$, respectively.

The ingredient tested in the present study was a commercially available leaf meal commonly used in poultry feeds. The composition of the reference diet, and the test diets, in which $10 \%, 20 \%, 30 \%, 40 \%$ and $50 \%$ of leaf meal was substituted to the reference diet are given in Ta- bles I and II. The diets were prepared by mixing the powdered ingredients in a Kenwood Chef Kitchen mixer, and pelleted in a Californian Pelleting machine.

Proximate analysis of the ingredients and diets were carried out using the following techniques: protein, using, Kjeltec 1030 (Tecator), to determine the total nitrogen and multiplying by 6.25; total lipid, using a Soxtec (Tecator); ash, by burning at $550^{\circ} \mathrm{C}$ in a muffle furnace for 12 h; crude fibre, using a Fibretec (Tecator) and energy, by burning in an excess of oxygen in a Gallenkamp micro-bomb calorimeter. $\mathrm{Cr}_{2} \mathrm{O}_{3}$ was estimated by the method of Furukawa and Tsukahara (1966).

Table I. The ingredient composition of the reference diet (RD) and the proximate composition of the individual ingredients (by \% dry weight). a, c - After Shim and Chua (1986); CMC - Carboxyl methyi cellulose used as a binder; all energy values are determined and expressed in $\mathrm{kJ} \cdot \mathrm{g}^{-1}$.

\begin{tabular}{lccccc}
\hline Ingredient & $\begin{array}{c}\text { RD } \\
\%\end{array}$ & Protein & Total lipid & Ash & Energy \\
& & & & & \\
\hline Fish meal & 23.0 & 58.2 & 9.4 & 28.9 & 19.71 \\
Glycine soya & 16.0 & 52.8 & 3.8 & 8.7 & 22.56 \\
Wheat bran & 21.0 & 16.9 & 6.5 & 3.5 & 21.63 \\
Wheat flour & 36.5 & 12.3 & 6.2 & 0.5 & 20.83 \\
Plant oil & 0.5 & - & 100.0 & - & 38.06 \\
Mineral mix & 1.0 & - & - & - & - \\
$\mathrm{CMCb}^{\mathrm{a}}$ & 0.73 & - & - & - & - \\
Vitamin mix & 0.27 & - & - & - & - \\
$\mathrm{Cr}_{2} \mathrm{O}_{3}$ & 1.00 & & - & - & - \\
& & & & & \\
\hline
\end{tabular}

Table II. The proximate composition of the experimental diets (by \% dry weight; LM - leaf meal). The proximate composition of leaf meal by dry matter was $16.5 \%$ protein; $5.7 \%$ total lipid; $10.0 \%$ ash, $20.5 \%$ crude fibre and $21.42 \mathrm{~kJ} . \mathrm{g}^{-1}$ energy.

\begin{tabular}{|c|c|c|c|c|c|}
\hline Diet & Protein & Total lipid & Ash & Fibre & $\begin{array}{l}\text { Energy } \\
k J \cdot g^{-1}\end{array}$ \\
\hline $\begin{array}{l}\text { Reference Diet (RD) } \\
\text { RD + } 10 \% \text { LM (D1) } \\
\text { RD + } 20 \% \text { LM (D2) } \\
R D+30 \% \text { LM (D3) } \\
\text { RD + } 40 \% \text { LM (D4) } \\
\text { RD + } 50 \% \text { LM (D5) }\end{array}$ & $\begin{array}{l}29.2 \\
28.6 \\
27.1 \\
25.5 \\
23.5 \\
22.7\end{array}$ & $\begin{array}{l}9.1 \\
5.7 \\
5.6 \\
5.7 \\
5.5 \\
5.4\end{array}$ & $\begin{array}{l}12.0 \\
11.1 \\
11.0 \\
10.9 \\
10.7 \\
10.6\end{array}$ & $\begin{array}{l}2.95 \\
4.2 \\
5.6 \\
6.4 \\
8.1 \\
9.2\end{array}$ & $\begin{array}{l}18.16 \\
19.83 \\
20.21 \\
20.83 \\
20.54 \\
20.92\end{array}$ \\
\hline
\end{tabular}


The apparent dry matter (DMD) and protein digestibility (PD) for each of the experimental diets were calculated using the following formulae:

$\%$ DMD $=100-100[$ (marker in feed $) \times(\%$ protein in faeces $)] /$ (marker in faeces) $\times(\%$ protein in feed)]

The apparent or the protein digestibility of the ingredient (in this case, leaf meal) was calculated:

100 [DMD of TD - (x/100) DMD of RD]

$$
[1-(x / 100) \text { DMD of TD] }
$$

where $X$ refers to the amount of test ingredient that was added to the test $\operatorname{diet}(\mathrm{s})$.

\section{RESULTS}

The percent dry matter digestibility and protein digestibility of the reference diet (RD) and test diets, in which leaf meal has been added in increments of $10 \%$ upto $50 \%$, estimated using $\mathrm{Cr}_{2} \mathrm{O}_{3}$ and crude fibre as markers on faeces voided in the night and during daytime, are given in table III.

Dry matter and protein digestibilities decreased with increasing levels of substitution of leaf meal, in all instances. It can also be seen from table III, that the SD of the digestibility estimates, made using $\mathrm{Cr}_{2} \mathrm{O}_{3}$ as a marker on faeces voided in the night, increased with an increasing level of substitution of leaf meal in the diets. Such a trend was not apparent in the other instances. For any one particular diet, dry matter or protein digestibility estimates, based on faeces voided in the daytime or the night, were not significantly different from each other $(P>0.05)$, irrespective of the marker used. However, the variance of estimates, based on faeces voided in the night, tended to be higher. The dry matter and protein digestibilities estimated on day time faeces was consistently slightly higher when crude fibre was used as the marker; this trend was not apparent in the case of faeces voided in the night.

The relationship of the changes in dry matter and protein digestibilities of the 2 groups of faeces, estimated using the 2 markers, to the level of substitution of leaf meal in the diets are shown in Figs 1 and 2. The dry matter and protein digestibilities were related linearly to the $\%$ of substitution of leaf meal in the diet, \% fibre and \% ash content of the diets (table IV). For any one dietary variable, the relationships were not significantly different $(P<0.05)$ for estimates made using either marker, or faecal material, voided during day or night. Also, the correlation of the relationships in all instances, decreased with the \% of leaf meal, fibre and ash in the diet in that order (table IV). However, there was no statistically significant relationship of the apparent dry matter or the protein digestibility to the dietary protein content $(P>0.05)$.

Dry matter and protein digestibility of leaf meal, estimated from faeces voided in the daytime and in the night and using $\mathrm{Cr}_{2} \mathrm{O}_{3}$ and crude fibre as markers in $\mathrm{O}$ aureus fed diets containing different amounts of leaf meal, are given in table $\mathrm{V}$. The apparent dry matter and protein digestibility estimations of the ingredient showed a higher variance. In most instances, the estimations differed significantly when $O$ aureus were fed the diet containing $10 \%$ leaf meal, from the others, when the differences were not significant $(P>0.05)$. For any 1 diet, the dry matter or protein digestibility estimations did not differ significantly $(P>0.05)$, irrespective of the time of collection or the marker used, with one exception : in $O$ aureus fed diet D1, dry matter digestibility estimated using crude fibre as 


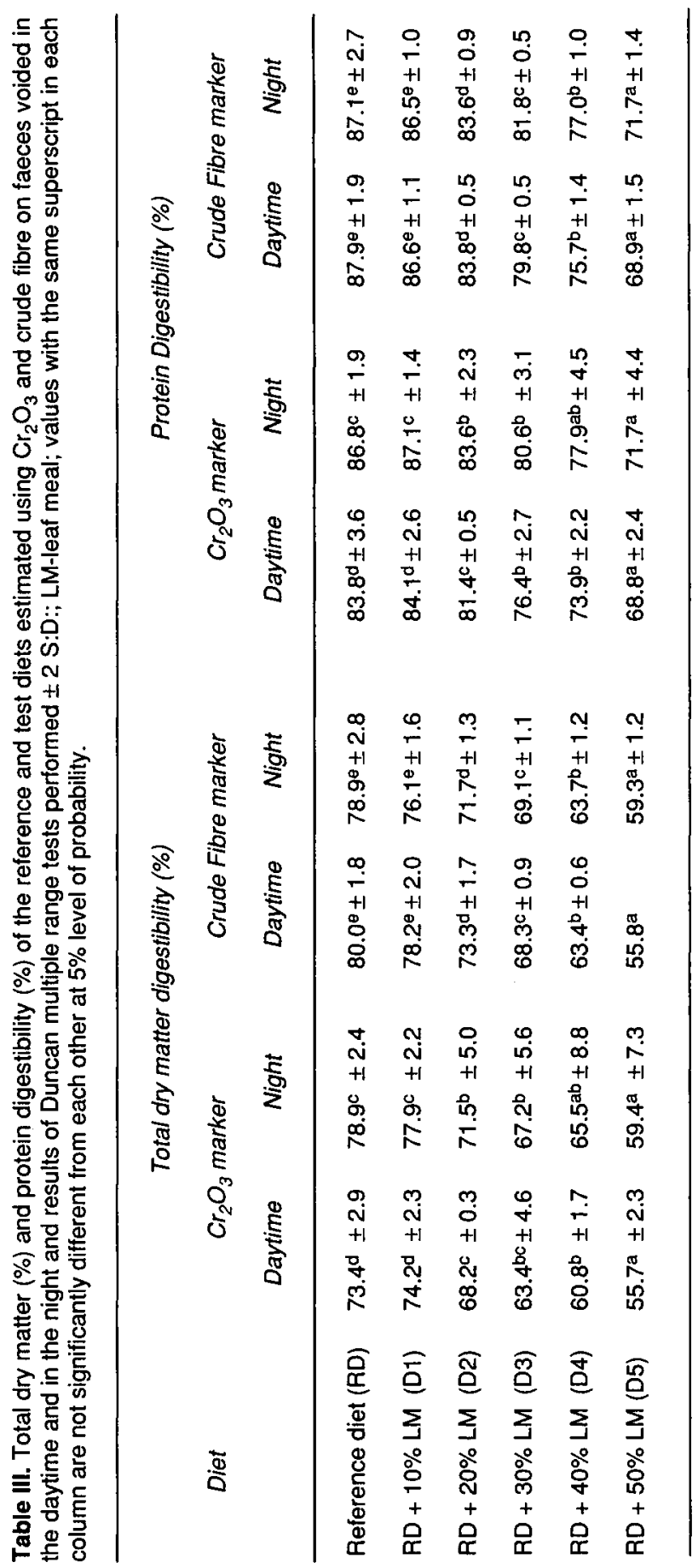




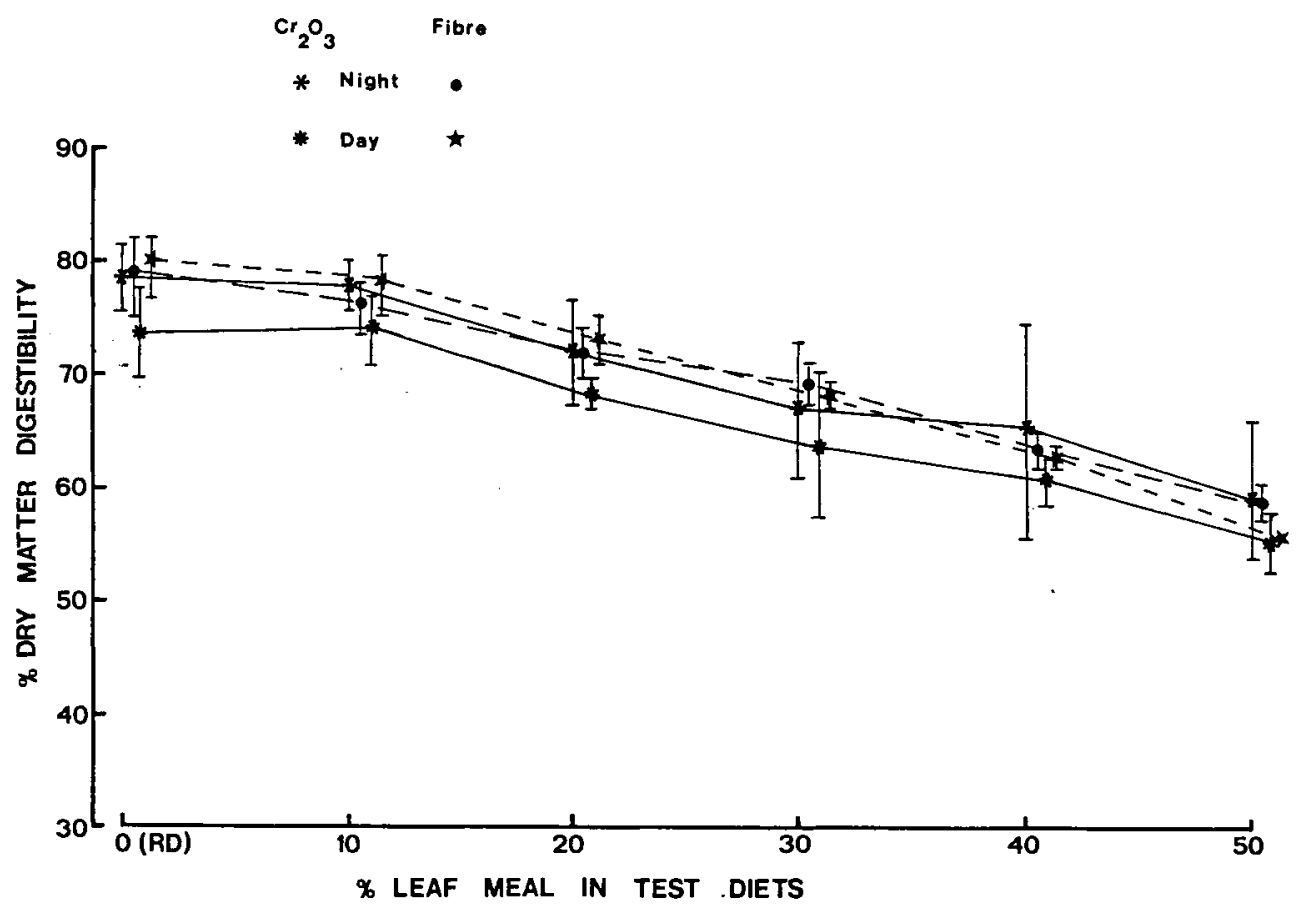

Fig 1. Changes in the apparent dry matter digestibility (DMD) of the reference diet (RD) and test diets in relation to the level of substitution of the test ingredient based on faecal matter voided in the night and daytime, and using $\mathrm{Cr}_{2} \mathrm{O}_{3}$ and crude fibre as markers. The lines are drawn by eye and do not represent the lines of best fit. The vertical lines represent \pm 2 SD.

a marker, differed significantly (Students $t$ test; $P<0.05$ ) from that based on $\mathrm{Cr}_{2} \mathrm{O}_{3}$.

The percentage of dry matter digestibility is curvilinearly related to the degree of substitution ( $\% \mathrm{~S}, \%$ crude fibre in leaf meal $\left(\mathrm{CF}_{\mathrm{Im}}\right)$ and the total amount of crude fibre in the diet $\left(C F_{t d}\right)$; the statistical relationships are given in table VI. The estimations of digestibility based on crude fibre as a marker, in all instances, were better correlated. The apparent protein digestibility of leaf meal was similarly curvilinearly related to the degree of substitution (S) of leaf meal in the test diets, \% crude fibre in leaf meal $\left(C F_{\mid m}\right)$ and \% leaf meal protein $\left(\mathrm{PR}_{\mathrm{ff}}\right)$, but was linearly related to the total protein in the diet $\left(\mathrm{PR}_{\mathrm{a}}\right)$.

\section{DISCUSSION}

In this study, faecal collections were made by simple siphoning. Admittedly, this is not ideal when compared to automatic faecal collection apparatus, such as those described by Cho et al (1982) and Choubert et al (1982). Nevertheless, as a standard procedure was adopted in the present 


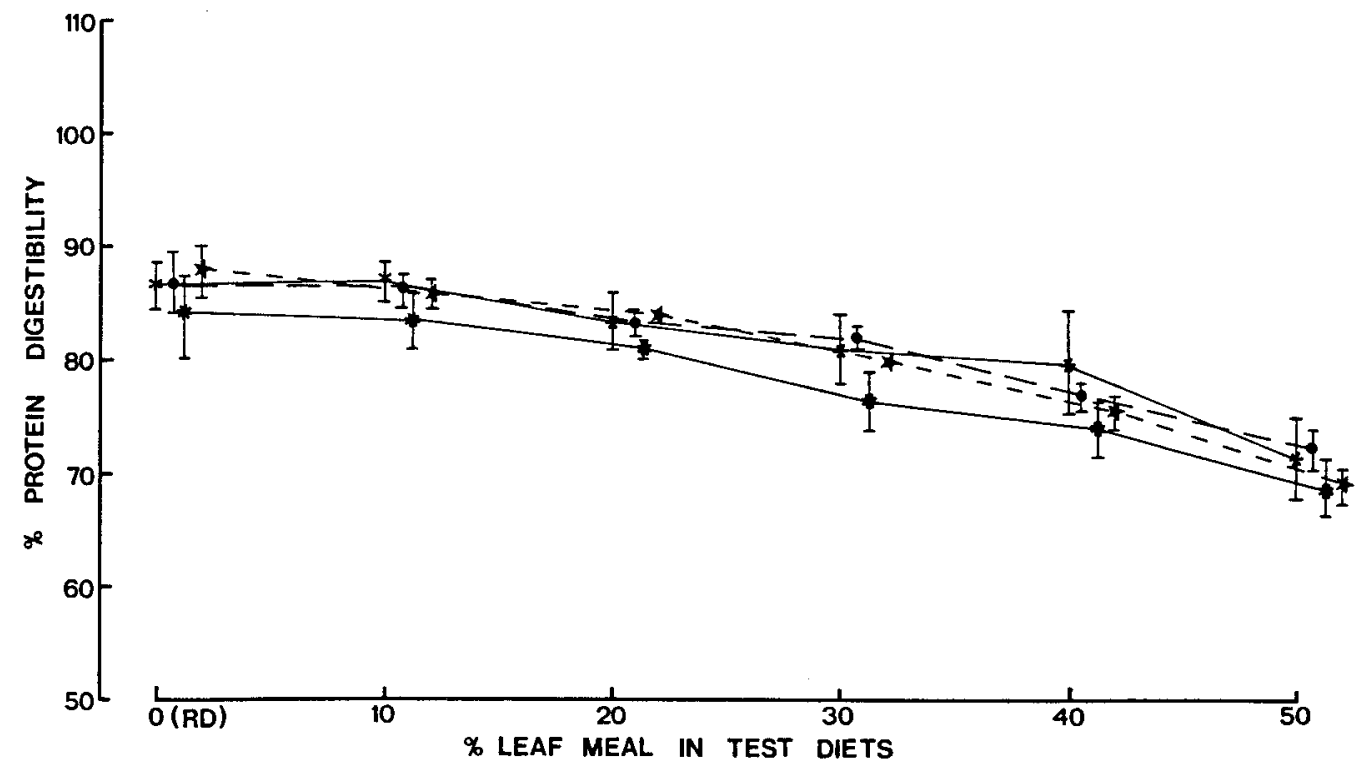

Fig 2. Changes in the apparent protein digestibility (PD) of the reference diet (RD) and test diets in relation to the level of substitution of the test ingredient, based on faecal matter voided in the night and daytime, and using $\mathrm{Cr}_{2} \mathrm{O}_{3}$ and crude fibre as markers. The lines are drawn by eye. The vertical lines represent \pm 2 SD.

experiments, it is thought that the results obtained are comparable and will not negate the findings to any significant degree.

Recently, Spyridakis et al (1988) in their study on European sea bass, concluded that continuous filtration apparatus was the most appropriate technique for digestibility trials, whereas Austreng (1978), advocated faecal collection from an area closest to the anus. The results of the present study indicate that there was no significant difference in the apparent dry matter or protein digestibility of a diet based on external marker, as opposed to an internal marker, and on the time of collection of the faeces. However, the variance of estimates based on faeces voided in the night was higher. These estimates were based by pooling collections from 4 nights, as opposed to those voided during the day which were based on collections pooled over 7 daytime periods. Such differences could occur due to differences in leaching and/or bacterial action. It is reported that leaching of nitrogenous compounds, in particular, stabilize after $1 \mathrm{~h}$ (Possompes, 1973). In this study, the bulk of the faecal material would have remained in water in excess of $1 \mathrm{~h}$. Also, as there was no difference in the mean values in the dry matter and protein digestibility estimates made from faeces collected during different times, it is possible that the bacterial action was also not directly responsible for the observed variance. On the other hand, digestibility is known to vary diurnally (De Silva and Perera, 1983, 1984). It is possible, due to the 
Table IV. The statistical relationships of \% dry matter digestibility (DM) and \% protein digestibility (PD) to the level of substitution of leaf meal (S), \% fibre (F) and \% Ash (As), in the experimental diets, estimated for faeces voided during daytime (dtf) and in the night (nf), and using $\mathrm{Cr}_{2} \mathrm{O}_{3}$ and crude fibre as markers. The correlation coefficients are given in parenthesis.

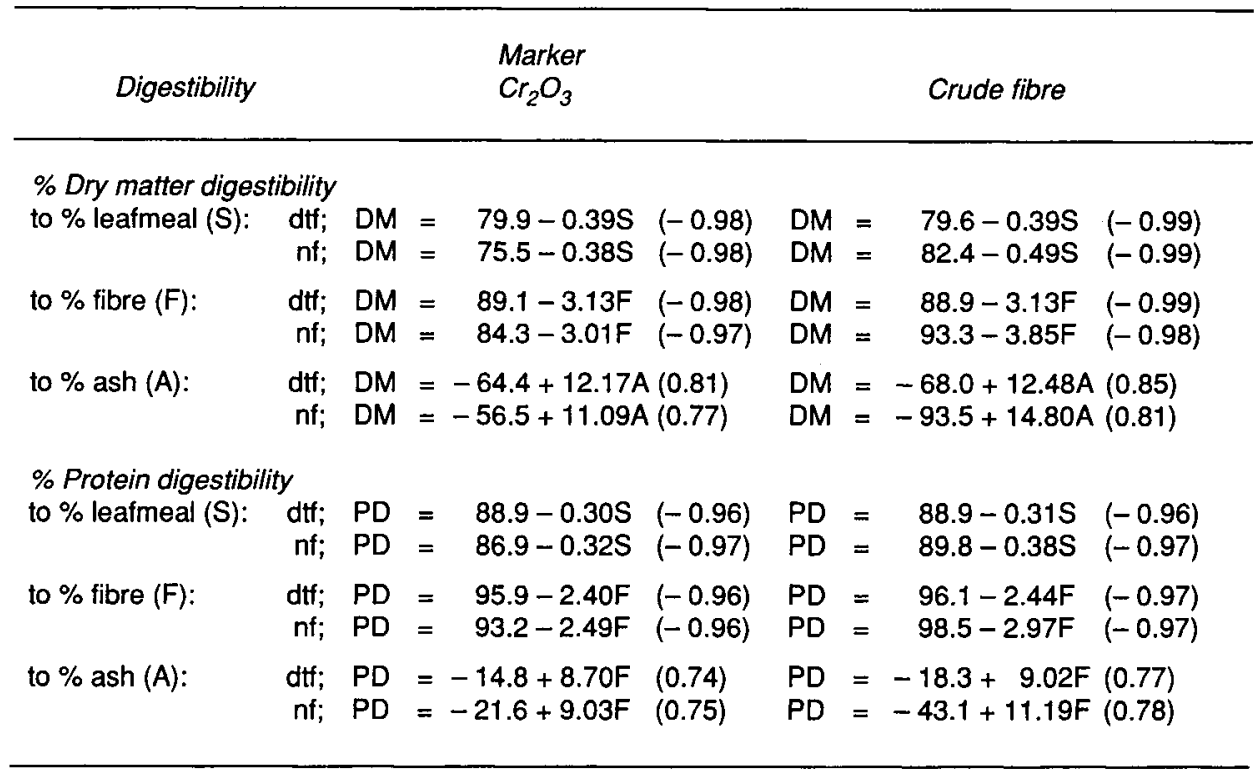

pooling of faecal material voided during the daytime over a larger number of days, that this variability is somewhat reduced as opposed to the estimates based on nightly voided faeces, which were pooled over $4 \mathrm{~d}$. This may indicate that pooling of faecal material over a longer period of time, up to $7 \mathrm{~d}$, is more desirable. The other possible reason for the observed variance, could be the bias that may result from the differences in the binding gradient in the experimental diets with increasing levels of inclusion of leaf meal. Such a gradient can result in a higher degree of leaching level of leaf meal in the test diets.

Digestibility is known to be influenced by many factors, amongst which are feeding level and meal size (Henken et al, 1985), size and age (Windell et al, 1978), dietary components (Rychly and Spannhof, 1979; Beamish and Thomson, 1984; Hanley, 1987; Spyridakis et al, 1989 ) and type of nutrient (Nose and Toyama, 1966). Hanley (1987) did not find a link between crude protein content of the diet to its digestibility in Oreochromis niloticus. On the other hand, Rychly and Spannhof (1979) observed that the total digestibility decreased with decreasing protein content. In the present study, both the dry matter and protein digestibilities decreased with increasing ash and fibre content, and with the decreasing dietary protein content; trends were mathematically significant. Significant mathematical relationships were derivable between dry mat- 


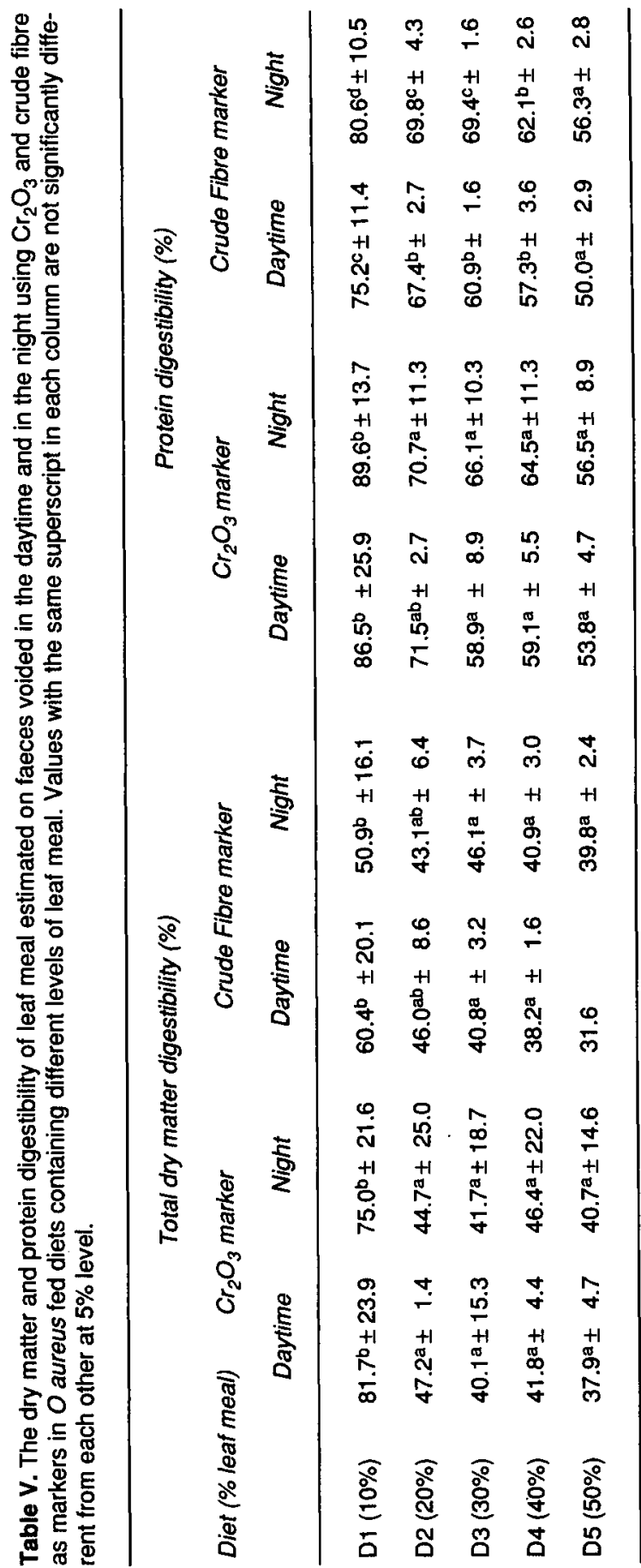


Table VI. Statistical relationship of \% apparent dry matter (DMD) and protein digestibility (PD) of the test ingredient leaf meal, to different parameters (S: \% substitution of leaf meal in test diets; $\mathrm{CF}_{1 \mathrm{k}}: \%$ crude fibre of leaf meal in the diet; $\mathrm{CF}_{\mathrm{Id}}: \%$ crude fibre in the whole diet; $\mathrm{Pr}_{\mathrm{Im}}$ : \% leaf meal protein; $\mathrm{P}_{\mathrm{Rd}}: \%$ total protein in the diet) estimated using $\mathrm{Cr}_{2} \mathrm{O}_{3}$ and crude fibre as markers (the correlation coefficients are given in parenthesis; in these computations the faeces voided in the daytime and in the night were not treated separately).
\% Digestibility
$\mathrm{Cr}_{2} \mathrm{O}_{3}$ marker
Crude fibre markers

Dry matter (DMD):

\begin{tabular}{|c|c|c|c|c|}
\hline $\begin{array}{l}D M D=176.77 \mathrm{~S}^{-0.399} \\
\mathrm{DMD}=93.78 \mathrm{CF}_{\mathrm{II}^{-0.399}} \\
\mathrm{DMD}=200.31 \mathrm{CF}_{\mathrm{td}}^{-0.766}\end{array}$ & $\begin{array}{l}(-0.91) \\
(-0.91) \\
(-0.84)\end{array}$ & $\begin{array}{l}\text { DMD }= \\
\text { DMD }= \\
\text { DMD }=\end{array}$ & $\begin{array}{l}=99.61 \mathrm{~S}^{-0.255} \\
=66.42 \mathrm{CF}_{1 \mathrm{~m}}{ }^{-0.254} \\
=115.66 \mathrm{CF}_{\mathrm{td}}-0.526\end{array}$ & $\begin{array}{l}(-0.98) \\
(-0.98) \\
(-0.98)\end{array}$ \\
\hline
\end{tabular}

Proteins (PD):

$\begin{array}{ll}P D=165.31 S^{-0.278} & (-0.99) \\ P D=106.44 C F_{1 m}-0.277 & (-0.99) \\ P D=100.21 P R_{1 m}-0.277 & (-0.99) \\ P D=-54.81+4.81 P R_{d} & (0.93)\end{array}$

$$
\begin{aligned}
& P D=131.6 S^{-0.219} \\
& P D=92.92 \mathrm{CF}_{\mathrm{Im}}-0.219 \\
& P D=88.61 \mathrm{PR}_{\mathrm{Im}}^{-0.218} \\
& P D=29.94+3.72 \mathrm{PR}_{\mathrm{d}}
\end{aligned}
$$

ter and protein digestibilities to the degree of substitution of the test ingredient in the diet, as was reported by Spyridakis et al (1988) for European sea bass, when casein-gelatin mixture and soybean were substituted into a reference diet. Fibre is known to reduce the utilization of many nutrients. However, existence of mathematical relationships of dietary crude fibre or other nutrient components to the digestibility of diets, have not been hitherto shown . The present findings, as well as those of Spyridakis et al (1988) indicate the possibility of estimating the apparent digestibility of an ingredient based on mathematical relationships between the observed digestibility of test diets to the amount of ingredient incorporated, as well as the quantum of crude fibre etc, in the diet. It should be pointed out, however, that this extrapolation may not be possible with other raw materials, and needs further investigation on the applicability of the observations in general.
The validity of Cho et al (1982) method of mixing $30 \%$ of the test ingredient with the reference diet, to evaluate the digestibility of the former was not tested earlier. The present study indicates that both dry matter and nutrient (protein) digestibility estimates are mathematically (curvilinearly) related to the amount of ingredient added to the reference diet, as well as on the crude fibre content of the ingredient and the total amount in the diet. Spyridakis et al (1988), however, noted that protein digestibility estimates for European sea bass, using the highest level of ingredient substitution, was close to those estimations obtained by linear regression.

The present results indicate 2 apparent trends. First, digestibility estimations decrease with increasing levels of incorporation of the test ingredient, leaf meal; the differences in estimations becoming progressively smaller beyond $20 \%$ level of incorporation. Second, the variance in the digestibility estimations decrease with the 
increasing level of test ingredient in the experimental diets, indicating that the accuracy of the determinations increase with increasing levels of the test ingredient, especially when crude fibre is used as the marker. This is to be expected because the analysis of crude fibre becomes relatively more reliable when an appreciable quantity is available in the diets. Considering both these factors, and that the main inflection of the curves depicting the relationship of total dry matter and protein digestibility occurs at $15 \%-20 \%$ level of inclusion of the test ingredient, it is suggested that this level of inclusion of the test gradient is the most desirable for estimating its digestibility. This is much less than that recommended by Cho et al (1982). It will be useful to make further investigations based on other ingredients and different species of fish before further generalizations are made on this aspect.

\section{ACKNOWLEDGMENTS}

We are grateful to Mr WL Chua for his technical assistance and to Ms O Yap for preparing the Figures.

\section{REFERENCES}

Austreng $E$ (1978) Digestibility determinations in fish using chromic oxide marker and analysis of contents from different segments of the gastrointestinal tract. Aquaculture 13, 265272

Bowen SH (1978) Chromic acid assimilation studies - a caution. Trans Am Fish Soc 107, 755-756

Beamish FW, Thomas E (1984) Effect of dietary lipid nitrogen losses in rainbow trout Salmo gairdneri. Aquaculture 41, 359-371

Cho CY, Slinger SJ, Bayley HS (1982) Bioenergetics of Salmonid fishes, energy intake, expenditure and productivity. Comp Biochem Physiol 73B, 25-41
Cho CY, Cowey CB, Watanabe T (1985) Finfish nutrition in Asia. Methodological approaches to research and development. Int Dev Res Cent Publ (Canada), Ottawa, Ontario, 154

Choubert G, De La Noue J, Luquet P (1982) Digestibility in fish: improved device for the automatic collection of faeces. Aquaculture 29, 185-189

De Silva SS, Perera MK (1983) Digestibility of an aquatic macrophyte by the cichlid Etroplus suratensis with observations on the relative merits of three indigenous components as markers and daily changes in protein digestibility. J Fish Biol 23, 675-684

De Silva SS, Perera MK (1984) Digestibility in Sarotherodon niloticus fry: effect of dietary protein level and salinity with further observations on daily variability in digestibility. Aquaculture 38, 293-306

Frukawa A, Tsukahara $H$ (1966) On the acid digestion method for the determination of chromic oxide as an index substance in the study of digestibility in fish feed. Bull Jap Soc Sci Fish 35, 502-506

Hanley $F$ (1987) The digestibility of foodstuffs and the effects of feeding selectivity on digestibility determinations on tilapia, Oreochromis niloticus. Aquaculture 66, 163-179

Henken AM, Kleingeld DW, Tjissen PAT (1985) The effects of feeding level on apparent digestibility of dietary dry matter, crude protein and gross energy in the African catfish Clarias gariepinus (Burchell 1822). Aquaculture $51,1-11$

Nose T, Toyama K (1966) Protein digestibility of brown fish meal in rainbow trout. Bull Freshwat Fish Res Lab 15, 213-224

Possompes BP (1973) Influence de la température sur les besoins en protéines, le transit alimentaire et la digestibilité chez la truite arc-en-ciel (Salmo gairdneri R). Thèse de $3^{\ominus}$ cycle, Université de Paris VI, 70 pp

Rychly J, Spannhof L (1979) Nitrogen balance in trout. I. Digestibility of diets containing varying levels of protein and carbohydrates. Aquaculture 16, 39-46

Shim KF, Chua YL (1986) Some studies on the protein requirement of the guppy, Poecillia reticulata (Peters). J Aquaricult Aqua Sci 4, 79-84 
Spyridakis P, Gabaudan J, Metailler R, Guillaume J (1988) Digestibilité des proténes et disponibilité des acides amines de quelques matières premières chez le bar (Dicentrarchus labrax). Reprod Nutr Dev 28, 1509-1517

Spyridakis P, Metailler R, Gabaudan J, Riaza A (1989) Studies on nutrient digestibility in European seabass (Dicentrarchus labrax). 1. Methodological aspects concerning faeces collection. Aquaculture 77, 61-70
Tacon AGT, Rodrigues AMP (1984) Comparison of chromic oxide, crude fibre, polyethylene and acid-insoluble ash as dietary markers for the estimation of apparent digestibility coefficient in rainbow trout. Aquaculture 43, 391-395

Windell JT, Foltz JW, Sarokon JA (1978) Effect of fish size, temperature and amount fed on nutrient digestibility of a pelleted diet by rainbow trout, Salmo gairdneri. Trans Am Fish Soc 107, 613-616 